\title{
Ammattikasvatushallinnon koulutuskeskus
}

Ammattikasvatushallinnon koulutuskeskus perustettiin tämän vuoden maaliskuun alusta eduskunnan säätämän lain ja myöntämien määrärahojen turvin. Laissa sanotaan: "Ammattikasvatushallinnon ja sen alaisen opetustoimen tehtäviä hoitavien henkilöiden lisäkoulutusta varten on ammattikasvatushallituksen alainen valtion ylläpitämä ammattikasvatushallinnon koulutuskeskus." Siinä on tehtävämme lyhyesti ja yksinkertaisesti ilmaistuna. Asetus täydentää kuitenkin tehtäväkuvaamme pitemmälle. Sen mukaan me järjestämme lisäkoulutusta; me tarjoamme oppilaitoksille asiantuntijapalveluja lisäkoulutuksen järjestämisessä; me huolehdimme lisäkoulutuksen kehittämisestä ja ajan tasalla pitämisestä; me teemme selvityksiä ja tutkimuksia lisäkoulutuksesta ja sen tarpeesta; sekä teemme aloitteita ja esityksiä lisäkoulutuksen ja tarvittaessa myös ammatillisen koulutuksen yleisestä kehittämisestä.

Edellä käytetty sana "me" tarkoittaa tässä vaiheessa viittä henkilöämme: kahta koulutussuunnittelijaa, kahta toimistosihteeriä ja tämän kirjoittajaa. Ensi vuonna meitä tullee olemaan kymmenen, jotta saamme hoidettua lain ja asetuksen langettamat tehtävät. Parin vuoden kuluttua, kun olemme päässeet omiin pysyviin tiloihimme ja toimintamme on vakiintunut meitä on ehkä parikymmentä, mutta siihen rajoitamme kasvumme. Pariinkymmeneen mahtuu jo nykyisten henkilöstönimikkeiden lisäksi asuntolahotellin hoitaja, talonmies, informaatikko, talouspäällikkö, ehkä muitakin.

\section{Tehtävien tarkastelua}

\begin{tabular}{|l|l|}
\hline $\begin{array}{l}\text { Asioiden } \\
\text { toteuttamiseen } \\
\text { liittyvä koulutus }\end{array}$ & $\begin{array}{l}\text { Aikuiskoulutuksen } \\
\text { sisäinen } \\
\text { kehittäminen }\end{array}$ \\
\hline $\begin{array}{l}\text { Tiedottava ja ajan } \\
\text { tasalla pitävä } \\
\text { koulutus }\end{array}$ & Konsultointi \\
\hline
\end{tabular}

Omissa kaavailuissamme olemme jakaneet tehtävämme edelläolevan nelikentän mukaisesti.

Ajankohtainen mittava koulutuspoliittinen ja yhteiskuntapoliittinen hanke on aikuiskoulutuksen kehittäminen. Siitä näyttää vallitsevan laaja kansallinen yhteisymmärrys. Valtioneuvosto on tehnyt kolme sitä koskevaa periaatepäätöstä; ensimmäisen vuonna 1978, jolloin jatkuva koulutus asetettiin aikuiskoulutuksen kehittämisen tavoitteeksi. Toinen periaatepäätös vuodelta 1987 sisälsi rahoitusperiaatteet eli kolmijaon omaehtoiseen koulutukseen, työllisyyskoulutukseen ja henkilöstökoulutukseen. Kolmas periaatepäätös tämän vuoden maaliskuulta asetti selviä tavoitteita aikuiskoulutuksen eteenpäin saattamiselle mainitun kolmijaon puitteissa.

Me pidämme laitostamme, Ammattikasvatushallinnon koulutuskeskusta, välineenä, jonka tehtävänä on saattaa eduskunnan tahtoa ja valtioneuvoston päätöksiä eteenpäin. Toimimme tällöin kiinteässä yhteistyössä opetusministeriön, ammattikasvatushallituksen ja lääninhallitusten kanssa. Vastaavasti mittava tehtävä tullee olemaan työllisyyskoulutuksen ja ammatillisten kurssikeskusten uudistaminen, josta ylijohtaja Leevi Melametsän johtama Kurssikeskustoimikunta on vast'ikään saanut mietinnön valmiiksi.

Lähdimme liikkeelle tänä syksynä kutsumalla Tampereelle koulutuskeskukseemme vastuuhenkilöiden ryhmiä opetusministeriöstä, ammattikasvatushallituksesta, lääninhallituksista ja oppilaitoksista. Kaikkien niiden kanssa olemme käyneet läpi keskeisiä aikuiskoulutuksen kehittämiselle asetettuja tavoitteita ja tarkastelleet mitä eri tasoilla olisi tehtävä asioiden saattamiseksi eteenpäin, mitä ongelmia nousee eteen ja kenen tehtävä on niitä ratkoa. Nähdäksemme tällainen massiivinen, tavoitetietoinen koulutus on asioiden toteuttamisessa mahtava keino - niinkuin se on kaikissa nykyaikaisissa kehittyvissä organisaatioissa. 


\section{Aikuiskoulutuksen sisäinen kehittäminen}

Toinen tehtäväkenttämme on yllä nimetty sanoilla "aikuiskoulutuksen sisäinen kehittäminen". Tarkoitamme sillä koulutusajattelun syventämistä, aikuispedagogiikan kehittämistä sekä tilaisuuksien luomista aikuiskouluttajille osallistua koulutukseen, jonka avulla he voivat kehittää itseään. Olemme itse osallisia tutkimus-, kokeilu- ja kehittämisprojekteissa, mutta erityisesti pyrimme seuraamaan yliopistojen ja tutkimuslaitosten työtä Suomessa ja ulkomailla ja saamaan siitä suuntaa ja herätettä koulutukseen. Tampereen yliopiston kanssa olemme neuvotelleet aikuiskouluttajatutkinnon aikaansaamisesta yliopistoon, jossa on ensimmäinen maan kahdesta pääprofessuurista. Toivomme hankkeen edistyvän, koska se toisi mahdollisuuden korkeatasoiseen opiskeluun ja, itsekkäästi ajatellen, kiinteyttäisi meidän ja yliopiston yhteistyötä.

Olemme alkaneet kerätä kirjastoa laitokseemme. Jo nyt siihen on kertynyt mukava kokoelma historiallisia ammatillista koulutusta ja työn kehittymistä käsitteleviä teoksia sekä kiintoisa joukko viime vuosien tutkimusraportteja maamme yliopistoilta ja muilta tutkimusta harjoittavilta laitoksilta. Vähitellen suuntaamme tilauksiamme myös ulkomaiden tutkimuslaitoksiin.

\section{Tiedottava ja ajan tasalla pitävä koulutus}

Otsikon kenttä on varmaan selkeä jo nimikkeensä perusteella. On luontevaa aina tilaisuuden tullen luoda katsaus ajankohtaisiin tapahtumiin, ja niin varmaan teemme jo yllä kerrotuissa koulutustilanteissa. Suunnitelmissamme on myös järjestää seminaareja, joissa käsitellään ammatillista koulutusta toisissa maissa tai tutkimuksen tilannetta tai muuta vastaavaa teemaa.

\section{Konsultointi}

Odotamme, että meille vähitellen kertyy muiden kenttien toiminnasta sellainen asiantuntemus ja kokemus, jota voimme myydä konsulttipalveluina oppilaitoksille, toisille hallinnonaloille, esimerkiksi työvoimahallinnolle, sekä mahdollisesti kunnille ja yrityksille. Tietämyksemme kertyy neljältä taholta: tutkimuksesta, kansainvälisistä yhteyksistämme, suorista kontakteista hallinnon kaikkiin tasoihin sekä oppi- laitoksilta. Yhteyksien muodostumisen suhteen olemme varsin ainutlaatuinen laitos. Kaipa se velvoittaakin.

\section{Ketä koulutamme?}

Lain perusteella olemme keskushallinnon henkilöstöä kouluttava laitos. Tulemme siis paneutumaan yhtä lailla johto-organisaation kuin suunnittelijoiden, tarkastajien, toimistohenkilöstön, vahtimestareiden ja kaikkien muiden virastoissa työskentelevien henkilöiden koulutukseen.

Vaikeammin tulkittavissa on lainkohdan jatko, jossa todetaan koulutuskeskuksen olevan myös ammattikasvatushallinnon alaisen opetustoimen tehtäviä hoitavien henkilöiden lisäkoulutusta varten. Olemme nähneet pääperiaatteeksi sen, että eri alojen opettajankoulutuslaitokset hoitavat ammatillisten opettajien lisäkoulutuksen, kukin omalla alallaan. Niillä on asianmukainen ympäristö ja niihin kertyy ajankohtainen ammatillinen tieto ja taito. Me tulemme toimimaan lähinnä oppilaitoshallinnon tehtävissä toimivien koulutuksessa. Tarkoitamme tällöin rehtoreita, apulais- tai vararehtoreita osastonjohtajia, talouspäälliköitä, toimistohenkilöstöä, asuntolanhoitajia, kuraattoreita ja muita vastaavia henkilöstöryhmiä. Yleisaineiden eli kaikille yhteisten aineiden opettajien lisäkoulutus voi suureksi osaksi tulla myös tehtäväksemme, koska heillä ei ole opettajankoulutuslaitosta niinkuin ammatillisilla opettaiilla. Jos me toimimme yleisaineiden opettajien koulutuksessa organisaattoreina, tulemme varmasti hakeutumaan yhteistyöhön yliopistojen ja korkeakoulujen kanssa, koska niistä löytyy eri oppiaineiden asiantuntemus. Sama koskee osittain myös muita toimintalohkojamme.

\section{Yhteistyötä}

Edellä tuli jo todettua työnjakoa ja yhteistyöpyrkimystä opettajankoulutuslaitosten ja yliopistojen sekä korkeakoulujen kanssa. Yhteistyötahona tullee olemaan myös Työvoimaopisto sekä Valtionhallinnon kehittämiskeskus. Näiden kaikkien tahojen kanssa toivomme pääsevämme reiluun yhteistyön henkeen siten, että sovimme koulutuksen järjestämisestä periaatteella: Se kouluttaa, joka parhaiten osaa asian. 